\title{
MOOD AND COPING FLEXIBILITY IN A GROUP OF ADOLESCENTS USING MARIJUANA
}

\section{NASTRÓJ A ELASTYCZNE RADZENIE SOBIE ZE STRESEM W GRUPIE MŁODZIEŻY SIĘGAJĄCEJ PO MARIHUANĘ}

\author{
Agnieszka Kruczek \\ Institute of Psychology, Department of Psychopathology and Clinical Diagnose, Kazimierz Wielki University in Bydgoszcz, Poland \\ Instytut Psychologii, Zakład Psychopatologii i Diagnozy Klinicznej, Uniwersytet Kazimierza Wielkiego w Bydgoszczy, Polska
}

Alcohol Drug Addict 2017; 30 (2): 85-102

DOI: https://doi.org/10.5114/ain.2017.70287

\begin{abstract}
Introduction: The purpose of the study was to assess mood and coping flexibility in group of adolescents using and not using marijuana, and recognise the nature of the relationship between mood and coping flexibility in the above mentioned groups.

Material and methods: A total of 129 persons (34 girls and 95 boys) were included in the study from 16 to 19 years of age. Mean age in the study group was $\mathrm{M}=17.36(\mathrm{SD}=1.01)$. The following methods were used in the study: UWIST Mood Adjective Checklist (UMACL) by Matthews, Jones and Chamberlain in Polish adaptation by Goryńska, Coping Flexibility Scale (CFS) by Kato in the Polish adaptation by Basińska et al. and socio-demographic questionnaire. Results: Data analysis show that there are no differences in flexible coping between adolescent users and non-users of marijuana. There are differences between these two groups in mood. Adolescents using marijuana experience low pleasure and more
\end{abstract}

\section{Streszczenie}

Wprowadzenie: Celem niniejszych badań była ocena nastroju i elastycznego radzenia sobie ze stresem $\mathrm{w}$ grupie młodzieży sięgającej i niesięgającej po marihuanę oraz określenie roli nastroju w elastycznym radzeniu sobie ze stresem $w$ tych grupach.

Materiał i metoda: Do badań zakwalifikowano 129 osób (34 dziewczęta i 95 chłopców) w wieku od 16 do 19 lat. Średnia wieku badanej próby wynosiła $\mathrm{M}=17,36$ ( $\mathrm{SD}=1,01)$.W badaniach wykorzystano Przymiotnikową Skalę Nastroju (UMACL) autorstwa Matthewsa, Jonesa i Chamberlaina w polskiej adaptacji Goryńskiej, Skalę Elastycznego Radzenia Sobie ze Stresem (CFS) autorstwa Kato w polskiej adaptacji Basińskiej i wsp. oraz ankietę własną.

Wyniki: Wykazano, że nie występują różnice w zakresie elastycznego radzenia sobie ze stresem między młodzieżą sięgającą i niesięgającą po marihuanę. Takie różnice mają natomiast miejsce w przypadku

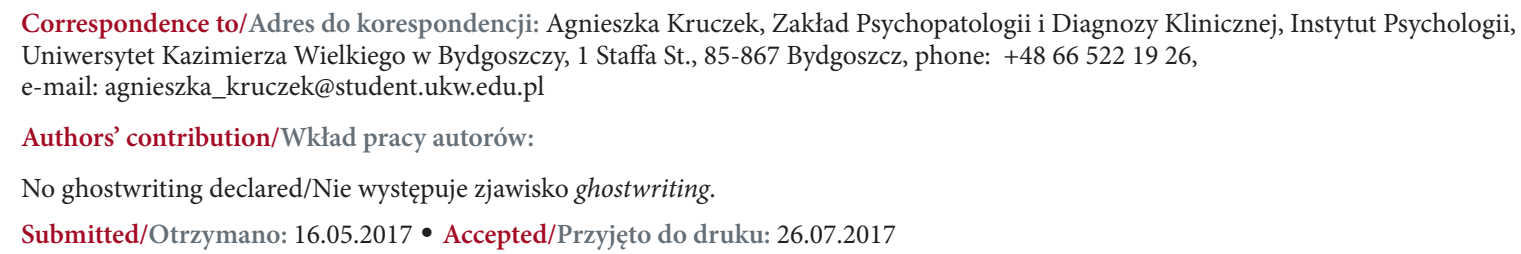


tense arousal than those not using marijuana. In the group of young people using marijuana there isn't any relationship between mood and coping flexibility. These relationships occur in the group of adolescents not using marijuana. Adolescents who present a higher level on the hedonic tone subscale were more effective in flexible coping. Those who present a higher level on the tense arousal subscale (anxiety-producing) were less effective in flexible coping.

Conclusions: Although a numerous of researches show relationships between coping strategies and using marijuana, the presented results did not confirm differences in coping flexibility between marijuana-using and non-using adolescents. A relationship between mood and coping flexibility has only been shown in adolescents not using marijuana.

Keywords: Coping flexibility, Mood, Adolescents, Marijuana use nastroju - młodzież sięgająca po marihuanę doznawała mniejszej przyjemności i większego pobudzenia napięciowego niż osoby niesięgające po marihuanę. W grupie młodzieży sięgającej po marihuanę stwierdza się brak istotnych statystycznie związków między nastrojem a elastycznym radzeniem sobie ze stresem. Takie związki występują w grupie osób niesięgających po marihuanę. Młodzież, która osiągała wyższe wyniki na podskali tonu hedonistycznego, była bardziej efektywna w elastycznym radzeniu sobie ze stresem. Młodzi ludzie, którzy prezentowali większe pobudzenie na podskali pobudzenia napięciowego (lękotwórczego), w mniejszym zakresie elastycznie radzili sobie ze stresem.

Wnioski: Chociaż liczne badania pokazują, że występują związki pomiędzy strategiami radzenia sobie ze stresem i sięganiem po marihuanę, to wyniki przeprowadzonych badań nie potwierdziły zróżnicowań w elastycznym radzeniu sobie ze stresem między młodzieżą sięgającą i niesięgającą po marihuanę. Związki pomiędzy nastrojem i elastycznym radzeniem sobie wykazano jedynie w grupie młodzieży niesięgającej po marihuanę.

Słowa kluczowe: elastyczne radzenie sobie ze stresem, nastrój, adolescenci, sięganie po marihuanę

\section{- INTRODUCTION}

Adolescents today are faced with numerous challenges and their associated stress is significantly different to what their parents had to face $[1,2]$. Initially, relations between adolescents and their parents are strained, only for this to gradually make way for situations related to academic achievements and concerns about the future [3-5]. Adolescents are also exposed to the numerous stressors of daily life, which situates them in the high-risk group in terms of the shaping of a negative mood, and in many cases, mental problems including the use of psychoactive substances $[2,6,7]$.

Coping with stress is a decisive condition of mental health, and its effectiveness depends to a great extent on the coping strategies applied [6, $8,9]$. Effectiveness may be achieved only when the stress situation is correctly assessed and the coping strategy selected is adequate to the situation [10]. It can be said that when the appropriate coping strategies are selected, the individual experiences positive emotions [6], while failure

\section{- WPROWADZENIE}

Przed współczesną młodzieżą stoją liczne wyzwania, a związany z nimi stres w sposób znaczący różni się od tego, $\mathrm{z}$ jakim mierzyli się ich rodzice $[1,2]$. Początkowo najbardziej obciążone są relacje młodzieży z rodzicami, stopniowo ustępując miejsca sytuacjom związanym $z$ osiągnięciami w nauce i obawom o przyszłość [3-5]. Młodzież staje także w obliczu licznych stresorów dnia codziennego, co sytuuje ją w grupie podwyższonego ryzyka, jeśli chodzi o kształtowanie się negatywnego nastroju, a w wielu przypadkach problemów psychicznych, włączając $\mathrm{w}$ to sięganie po substancje psychoaktywne $[2,6,7]$.

Radzenie sobie ze stresem stanowi decydujący warunek zdrowia psychicznego, a jego skuteczność $\mathrm{w}$ dużej mierze zależy od wykorzystywanych strategii radzenia sobie $[6,8,9]$. Efektywność można osiągnąć tylko wówczas, gdy sytuacja stresująca jest trafnie oceniona, a strategie radzenia sobie dobrane adekwatnie do sytuacji [10]. Można powiedzieć, że kiedy są wykorzystywane odpowiednie strategie radzenia sobie, jednostka doświadcza pozytywnych emocji [6], 
to select a correct strategy may lead to mental problems $[6,11]$.

Coping flexibility refers to intra-individual variability in terms of the application of a variety of strategies for coping with stress. It makes up the individual's capacity to effectively modify these strategies depending on the requirements presented by the stressful situation [12]. Flexible coping with stress may be understood as a measure of adapting between applied strategies and the nature of the circumstances in which these strategies are engaged $[10,13]$. Researches show that flexible coping with stress is associated with a lower probability of depression symptom occurrence and thus low mood in the face of stressful life events $[14,15]$.

The degree of flexible coping with stress is dependent on age and level of functioning in terms of cognitive processes $[9,16,17]$. It is therefore possible to pose the hypothesis that adolescents have a smaller capacity for flexible coping with stress and a quite narrow repertoire of coping behaviour in difficult situations [18]. In the light of research, it seems that adolescents apply problem-solving strategies for coping with stress less frequently, as is the case for cognitive restructuring and acceptance of responsibility, and so adaptive strategies [19]. Instead, adolescents prefer passive coping like acceptance, distancing themselves or wishful thinking [20-24]. Research reveals that adolescents more frequently coped with difficult situations by avoiding the solution of problems [20,21], instead resorting to drink, cigarette smoking or psychoactive substance use [20-23].

As is apparent from current studies, marijuana is the most commonly-used drug by adolescents in the world and is in many cases a gateway drug that proceeds the initiation of the use of other substances [25-30]. Current epidemiological data indicates that around 19\% of Polish 15 to 16-yearolds smoke marijuana or use other cannabis derivatives. This proportion is higher among 17-18 year-olds at $32 \%$ [30]. The research results are ambiguous as far as the occurrence of variation in the scope of marijuana use and place of residence. Studies by Woynarowska and Mazur [31] reveal the proportion of 13 to 15 -year-olds using drugs as higher in towns (24\%) than in rural areas (19\%). Other studies by Woynarowska [32] reveal that the proportion of adolescents using marijuana was independent of place of residence. podczas gdy niepowodzenie $\mathrm{w}$ tej dziedzinie może prowadzić do problemów psychicznych $[6,11]$.

Elastyczne radzenie sobie ze stresem odnosi się do intraindywidualnej zmienności w zakresie stosowania różnorodnych strategii radzenia sobie ze stresem. Stanowi o zdolności jednostki do efektywnej modyfikacji tych strategii w zależności od wymagań, jakie niesie ze sobą stresująca sytuacja [12]. Elastyczne radzenie sobie ze stresem może być rozumiane jako miara dopasowania między strategiami, które są wykorzystywane, i naturą okoliczności, w jakie są one zaangażowane [10,13]. Badania pokazują, że elastyczne radzenie sobie ze stresem jest związane z mniejszym prawdopodobieństwem wystąpienia objawów depresyjnych, w tym obniżonego nastroju, w obliczu stresujących wydarzeń życiowych $[14,15]$.

Stopień elastycznego radzenia sobie ze stresem zależy od wieku i poziomu funkcjonowania w zakresie procesów poznawczych $[9,16,17]$. Można zatem postawić hipotezę, że osoby w wieku młodzieńczym mają mniejszą zdolność do elastycznego radzenia sobie ze stresem i dość ograniczony repertuar zachowań służących do radzenie sobie z trudną sytuacją [18]. W świetle badań, młodzież rzadziej korzysta ze strategii radzenia sobie ze stresem polegających na rozwiązaniu problemu, poznawczej restrukturyzacji oraz akceptowaniu odpowiedzialności, a więc strategii adaptacyjnych [19]. Preferuje raczej pasywne radzenie sobie, tj. akceptację, dystansowanie się czy myślenie życzeniowe [20-24]. Badania pokazują, że adolescenci częściej radzili sobie z trudnymi sytuacjami przez unikanie rozwiązywania problemów [20, 21], w zamian sięgając po alkohol, paląc papierosy i odurzając się substancjami psychoaktywnymi [20-23].

Jak wynika ze współczesnych badań marihuana jest narkotykiem najczęściej używanym przez adolescentów na świecie, a w wielu przypadkach - narkotykiem progowym, tzn. poprzedzającym inicjację zażywania innych substancji psychoaktywnych [25-30]. Aktualne dane epidemiologiczne wskazują, że ok. 19\% polskich 15-16-latków pali marihuanę lub używa innych przetworów konopi. Wśród 17-18-latków odsetek ten jest wyższy i wynosi $32 \%$ [30]. Wyniki badań są niejednoznaczne, jeśli chodzi o występowanie zróżnicowań $\mathrm{w}$ zakresie używania marihuany ze względu na miejsce zamieszkania. W świetle badań Woynarowskiej i Mazur [31] odsetek 13-15-latków używających substancji psychoaktywnych w mieście był większy (24\%) niż na wsi (19\%). Z innych badań Woynarowskiej [32] wynikało, że odsetek młodzieży używającej marihuanę 
Numerous studies on the reasons for adolescent marijuana use indicate the occurrence of relations between marijuana use, the experience of stress and coping with stress. Nancy Low et al. [2] showed that young people most often smoked marijuana due to stress associated with the family situation like parental divorce or separation. In this case, the smoking of marijuana may have been an escape mechanism from family problems. It could also have been an attempt to attract the attention of the separating parents, an expression of rebellion against the changing family situation or desire to gain peer-group approbation. Xintao Liu [33] has confirmed that marijuana use was positively correlated with maladaptive coping strategies to stress of an avoidance character as well as emotion-focused strategies. Avoidance tendencies in difficult situations, together with the lack of success in social relations mainly of a peer-group nature, turned out to be significantly linked to Swiss adolescents' dependency on drugs including cannabis [34].

The lack of effectiveness of selected strategies for dealing with stress, including the use of maladaptive strategies (e.g. resorting to marijuana) induces a negative mood $[7,10,33]$. Low mood has a disadvantageous effect on the individual's way of thinking. One can therefore talk about a negative feedback loop between the applied maladaptive coping methods for stress and low mood $[9,35]$. In the presented study, we accepted Russell and Feldman Barrett's [36] understanding of mood who defined mood as a prolonged core affect. As opposed to emotions, mood is not associated to any object or is associated with a quasi-object. It refers to all temporary emotional states and also includes states linked to de-activation and low energy level. The mood is strongly determined not only by external events and experiences but also internal processes [37]. Mood, as opposed to emotion, may last a few hours, or even days [38].

The aim of this study was to assess mood and flexible coping with stress in a group of adolescent users and non-users of marijuana and to define the role of mood in flexible coping with stress in these groups.

The following research questions were formulated:

1. Are there differences with respect to flexible coping with stress among adolescent users and nonusers of marijuana? był niezależny od miejsca jej zamieszkania. Liczne badania poszukujące etiologii sięgania przez młodzież po marihuanę wskazują na występowanie związków między używaniem marihuany a odczuwaniem stresu i radzeniem sobie z nim. Nancy Low i wsp. [2] wykazali, że młodzi ludzie najczęściej palili marihuanę ze względu na stres związany z sytuacją rodzinną - rozwodem rodziców czy ich separacją. W tym przypadku palenie marihuany mogło stanowić mechanizm ucieczki od problemów rodzinnych lub też próbę skupienia na sobie uwagi rozstających się rodziców, wyraz buntu wobec zmiany sytuacji rodziny czy chęć zyskania aprobaty ze strony grupy rówieśniczej. Także badania Xintao Liu [33] potwierdzają, że sięganie po marihuanę było pozytywnie skorelowane z nieadaptacyjnymi strategiami radzenia sobie ze stresem o charakterze unikowym, jak również ze strategiami skoncentrowanymi na emocjach. Tendencje do unikania $\mathrm{w}$ trudnej sytuacji wraz $\mathrm{z}$ niepowodzeniami w relacjach społecznych, głównie rówieśniczych, okazały się istotnie powiązane $\mathrm{z}$ uzależnieniem młodzieży szwajcarskiej od substancji psychoaktywnych, w tym od konopi indyjskich [34].

Brak efektywności wybieranych strategii radzenia sobie ze stresem, w tym wykorzystywanie strategii nieadaptacyjnych (np. sięganie po marihuanę), indukuje negatywny nastrój [7, 10, 33]. Obniżony nastrój wywiera niekorzystny wpływ na sposób myślenia jednostki. Można zatem mówić o pętli negatywnego sprzężenia zwrotnego między stosowaniem nieadaptacyjnych metod radzenia sobie ze stresem a obniżonym nastrojem $[9,35]$. W prezentowanych badaniach przyjęto rozumienie nastroju za Russellem i Feldman Barrett [36], którzy definiują nastrój jako przedłużający się rdzenny afekt. W przeciwieństwie do emocji, nastrój nie wiąże się z żadnym obiektem lub jest związany z quasi-obiektem. Nastrój odnosi się do wszystkich przejściowych stanów uczuciowych. Obejmuje także stany związane $\mathrm{z}$ dezaktywacją i niskim poziomem energii. Na nastrój silnie wpływają nie tylko zewnętrzne zdarzenia i doświadczenia, lecz także wewnętrzne procesy [37]. Nastrój, w przeciwieństwie do emocji, może trwać kilka godzin, a nawet dni [38].

Celem niniejszych badań była ocena nastroju i elastycznego radzenia sobie ze stresem w grupie młodzieży sięgającej i niesięgającej po marihuanę oraz określenie roli nastroju w elastycznym radzeniu sobie ze stresem w tych grupach.

Sformułowano następujące pytania badawcze:

1. Czy występują różnice w zakresie elastycznego radzenia sobie ze stresem pomiędzy młodzieżą sięgającą i niesięgającą po marihuanę? 
2. Are there differences in mood between adolescent users and non-users of marijuana?

3. Are there relations between mood and flexible coping with stress in the adolescent groups of marijuana users and non-users?

\section{- Material and methods}

The study was conducted at school in small work groups by the researcher (the study's author), who applied an auditory method survey. Written parental consent was a condition of participation. During the study, in each of the groups, the researcher read out the instructions and informed the students of the anonymity of the study and the possibility of withdrawal of participation. Also, the students received written confirmation of the full anonymity of the study both at the level of individuals and the whole school. The results were therefore confidential at the school level. Teachers were not present in the class during the study. Sample selection based on data availability was used.

The study involved 129 subjects ( 34 girls and 95 boys) from 16 to 19 years-of-age. Average age was $\mathrm{M}=17.36(\mathrm{SD}=1.01)$ and $\mathrm{M}=17.29(\mathrm{SD}=0.52)$ for girls and $\mathrm{M}=17.38$ ( $\mathrm{SD}=1.14$ ) for boys. The subjects attended a basic vocational school $(n=78 ; 60 \%)$ and a technical school $(n=51 ; 40 \%)$. A large majority of subjects were from rural areas $(n=84 ; 65 \%)$ and small towns $(n=31 ; 24 \%)$.

The UWIST ${ }^{1}$ Mood Adjective Checklist (UMACL) by Matthews, Jones and Chamberlain was applied, in the Polish adaptation by Goryńska [38]. The tool is used to measure mood understood as an affective experience of a medium duration and no associated to object. UMACL is made up of 29 items in the form of adjectives that represent a subjective assessment of the experienced mood. The subject's task is to provide one of four possible answers - definitely yes, rather yes, rather no and definitely no, defining to what degree each of the adjectives express his current mood.

The UMACL results are presented in the form of three subscales: the Hedonic Tone (HT) - subjective pleasent/unpleasent feelings, Tense Arousal (TA) - these can be described as anxiety-producing and Energetic Arousal (EA) - energy for action [39].

${ }^{1}$ UWIST - University of Wales Institute of Science and Technology
2. Czy występują różnice w nastroju między młodzieżą sięgającą i niesięgającą po marihuanę?

3. Czy występują związki między nastrojem a elastycznym radzeniem sobie ze stresem $\mathrm{w}$ grupie młodzieży sięgającej i niesięgającej po marihuanę?

\section{- Materiat I metody}

Badania zostały przeprowadzone osobiście przez autorkę w klasach szkolnych, w małych grupach ćwiczeniowych, $\mathrm{z}$ wykorzystaniem metody ankiety audytoryjnej. Warunkiem przystąpienia młodzieży do badania było przedstawienie pisemnej zgody rodziców. Podczas badania w każdej z grup badaczka odczytywała instrukcję oraz informowała uczniów o anonimowości badania i możliwości rezygnacji $\mathrm{z}$ udziału w nim. Ponadto, uczniowie w pisemnej instrukcji otrzymali zapewnienie o pełnej anonimowości badań, zarówno na poziomie pojedynczych osób, jak i całej szkoły. Oznacza to, że tajemnicą objęte są również wyniki na poziomie szkół. Podczas badania nauczyciel nie był obecny w klasie. Wykorzystano dobór do próby oparty na dostępności danych.

Do badań zakwalifikowano 129 osób (34 dziewczęta, 95 chłopców) w wieku 16-19 lat. Średnia wieku badanej próby wynosiła $\mathrm{M}=17,36(\mathrm{SD}=1,01)$; dla dziewcząt $\mathrm{M}=17,29(\mathrm{SD}=0,52)$, dla chłopców $\mathrm{M}=17,38(\mathrm{SD}=1,14)$. Osoby badane były uczniami zasadniczej szkoły zawodowej $(n=78 ; 60 \%)$ i technikum $(n=51 ; 40 \%)$. Zdecydowana większość pochodziła ze wsi $(n=84 ; 65 \%)$ i małych miast $(n=31 ; 24 \%)$.

W badaniach wykorzystano Przymiotnikową Skalę Nastroju - UMACL (UWIST ${ }^{1}$ Mood Adjective Checklist) autorstwa Matthewsa, Jonesa i Chamberlaina, w polskiej adaptacji Goryńskiej [38]. Narzędzie to służy do pomiaru nastroju, rozumianego jako doświadczenie afektywne o umiarkowanym czasie trwania, niezwiązane z obiektem. UMACL składa się z 29 pozycji mających postać przymiotników, które stanowią o subiektywnej ocenie doświadczanego samopoczucia. Zadaniem osoby badanej jest udzielenie jednej z 4 możliwych odpowiedzi: zdecydowanie tak, raczej tak, raczej nie, zdecydowanie nie, określających, w jakim stopniu każdy z przymiotników odpowiada jej obecnemu nastrojowi.

Wyniki UMACL ujmowane są $\mathrm{w}$ postaci trzech podskal: Ton Hedonistyczny (TH) - subiektywne odczucie przyjemności-nieprzyjemności, Pobudzenie Napięciowe (PN) - można określić jako lękotwórcze,

${ }^{1}$ UWIST - University of Wales Institute of Science and Technology 
The starting point for constructing the tool was a concept of three bipolar mood dimensions. These were defind in the following way: energetic arousal EA described on a vigorous-tired poles, tense arousal TA on a nervous-relaxed poles and the hedonic tone HT on the pleasent-unpleasent mood poles. According to this concept, a good mood is associated with high HT and low TA levels. In the case of energetic arousal (EA), the authors suggest that high or moderate levels are to be sought after.

The scale's psychometric properties are satisfactory. The analysis confirms the high reliability of the subscales, which is relatively the highest for the HT subscale and lowest for the EA subscale. In the conducted study, the Cronbach's alpha indicator for the particular subscales is HT -0.88 , EA -0.88 , TA -0.86 .

The Coping Flexibility Scale (CFS) by Kato was applied in Basińska et al.s Polish adaptation [40]. The CFS measures the individual's capacity for effective coping strategy modification as required by the demands of a stressful situation. The scale is made up of 10 statements the subject responds to by indicating one of four possible answers: always relevant, often relevant, sometimes relevant and never relevant. The scale has satisfactory psychometrics, with a Cronbach alpha scale reliability of 0.87 [41]. In terms of validity and flexible coping correlate positively with cognitive flexibility and problem solving capacity of a social character [12]. The analysis covered only the global result in terms of flexible coping with stress. In the research carried out, the Cronbach's alpha reliability coefficient was 0.76 .

An own survey was applied in order to gather sociodemographic data and information on marijuana use. Subjects were asked how many times and how frequently in the last six months they had used marijuana. Among marijuana users $(n=50)$ the most had used it twice a week or more $(n=10 ; 20 \%)$ and twice a month $(n=27$; $54 \%$ ). In the subject literature, as with alcohol, the use of other drugs in the last 30 days is treated as an indicator of frequent contacts with these substances, which therefore allows identification of adolescents especially at risk of the negative consequences of their activity [42]. Furthermore, Ostaszewski et al. [43] points out that an indicator of frequent use is accepted as drug-use at least i Pobudzenie Energetyczne (PE) - energia do działania [39]. Punktem wyjścia do konstrukcji narzędzia stała się koncepcja trzech dwubiegunowych wymiarów nastroju. Zdefiniowano je w następujący sposób: pobudzenie energetyczne PE opisane na biegunach energiczny-zmęczony; pobudzenie napięciowe $\mathrm{PN}$ na biegunach zdenerwowany-zrelaksowany, oraz ton hedonistyczny TH - na biegunach przyjemnośćnieprzyjemność. W myśl tej koncepcji dobry nastrój związany jest $\mathrm{z}$ wysokim poziomem $\mathrm{TH}$ i niskim $\mathrm{PN}$. W przypadku interpretacji pobudzenia energetycznego (PE) autorzy sugerują, że pożądane są jego wysokie lub umiarkowane wartości.

Właściwości psychometryczne skali są zadowalające. Analizy potwierdzają wysoką rzetelność podskal, stosunkowo najwyższą dla podskali $\mathrm{TH}$, najniższą dla podskali PE. W przeprowadzonych badaniach rzetelność mierzona wskaźnikiem alfa Cronbacha dla poszczególnych podskal wynosi: $\mathrm{TH}-0,88, \mathrm{PE}-0,88, \mathrm{PN}-0,86$.

Zastosowano także Skalę Elastycznego Radzenia Sobie ze Stresem - CFS (The Coping Flexibility Scale), autorstwa Kato, w polskiej adaptacji Basińskiej i wsp. [40]. CFS bada zdolność jednostki do efektywnej modyfikacji strategii radzenia sobie w zależności od wymagań, jakie niesie ze sobą stresująca sytuacja. Składa się ona z 10 stwierdzeń, wobec których badany ustosunkowuje się, zaznaczając jedną z czterech możliwych odpowiedzi: zawsze dotyczy, często dotyczy, czasami dotyczy, nigdy nie dotyczy. Skala ma zadowalające właściwości psychometryczne. Rzetelność skali mierzona wskaźnikiem alfa Cronbacha wynosi 0,87 [41]. Trafność i elastyczne radzenie sobie korelują pozytywnie z elastycznością poznawczą i zdolnością rozwiązywania problemów o charakterze społecznym [12]. W analizach uwzględniono jedynie wynik globalny w zakresie elastycznego radzenia sobie ze stresem. W przeprowadzonych badaniach rzetelność mierzona współczynnikiem alfa Cronbacha jest równa 0,76.

W celu zebrania danych socjodemograficznych i informacji dotyczących używania marihuany zastosowano ankietę własną. Uczestników badania pytano o to, ile razy w ciągu ostatnich 6 miesięcy używali marihuanę i o częstość sięgania po nią. Spośród użytkowników marihuany $(n=50)$ najwięcej osób używało ją dwa razy w tygodniu lub częściej $(n=10 ; 20 \%)$ oraz dwa razy w miesiącu $(n=27 ; 54 \%)$. W literaturze przedmiotu, tak jak w przypadku alkoholu, używanie innych substancji psychoaktywnych w ostatnich 30 dniach traktowane jest jako wskaźnik częstych kon- 
ten or more times in the last year. On this basis, the subjects answers were coded as dichotomous variables indicating whether the given person used or did not use marijuana in the last 6 months [pos. 44]. The next question was about the age of drug-taking initiation, directly sensed physical and mental effects of marijuana and the subject's knowledge on the harmful effects of marijuana on the body. Persons who had ceased to use marijuana following initiation were eliminated from the sample as well as those who indicated on the survey that they would not currently take the drug.

\section{- Results}

Presentation of study results started with descriptive statistics and the characteristics of subjects' use of marijuana.

The average level of flexible coping with stress in the studied group was $\mathrm{M}=14.84(\mathrm{SD}=5.23)$. As far as mood was concerned, the subjects gained average scores in each of the subscales. The detailed data is presented in Table I. The girls were more effective at flexible coping with stress than boys. However, boys revealed a higher level of tense arousal (Table II).

According to the analysis, 50 subjects (39\%) had used marijuana in the last 6 months. Meanwhile, 79 (61\%) had never used this psychoactive substance. Taking into account the subjects' gender, more boys than girls used marijuana (Table III).

Most of the subjects declared they'd used marijuana twice in a month $(n=27 ; 21 \%)$, and the fewest that they used it every day $(n=1 ; 0.8 \%)$ (Table IV). The average age of drug taktów z tymi środkami, pozwala więc na identyfikację młodzieży szczególnie narażonej na negatywne konsekwencje ich działania [42]. Z kolei Ostaszewski i wsp. [43] wskazuje, że za wskaźnik częstego używania przyjmuje się sięganie po narkotyki przynajmniej kilkanaście razy w ostatnim roku. Na tej podstawie odpowiedzi badanych zostały zakodowane jako zmienne dychotomiczne wskazujące, czy dana osoba zażywała marihuanę, czy jej nie zażywała w ciągu ostatnich 6 miesięcy [por. 44]. W następnej kolejności zapytano o wiek inicjacji narkotykowej, odczuwane bezpośrednie skutki fizyczne i psychiczne działania marihuany oraz o posiadaną wiedzę na temat szkodliwości działania marihuany na organizm. $Z$ próby wykluczono osoby, które po inicjacji nie kontynuowały używania marihuany, oraz osoby, które wpisały w ankiecie, że nie będą aktualnie zażywać narkotyku.

\section{WYNIKI}

Prezentację wyników badań rozpoczęto od statystyk opisowych i charakterystyki używania marihuany przez badanych.

Średni poziom elastycznego radzenia sobie ze stresem $\mathrm{w}$ badanej grupie wyniósł $\mathrm{M}=14,84$ $(\mathrm{SD}=5,23)$. Biorąc pod uwagę nastrój, badani uzyskali przeciętne wyniki w każdej podskali. Szczegółowe dane zostały zamieszczone w tabeli I. Dziewczęta były bardziej efektywne, jeśli chodzi o elastyczne radzenie sobie ze stresem niż chłopcy. Chłopcy natomiast ujawniali wyższy poziom pobudzenia napięciowego niż dziewczęta (tab. II).

W świetle analiz 50 osób (39\%) używało marihuany w ciągu ostatnich 6 miesięcy. Natomiast 79 osób (61\%) nigdy nie zażywało tej substancji psychoaktywnej. Przy uwzględnieniu płci badanych, marihuany używał większy odsetek chłopców niż dziewcząt (tab. III).

Table I. Descriptive statistics of examined variables $(n=129)$

Tabela I. Statystyki opisowe badanych zmiennych $(n=129)$

\begin{tabular}{|l|c|c|c|c|}
\hline $\begin{array}{l}\text { Variables } \\
\text { Zmienne }\end{array}$ & M & SD & Min. & Max. \\
\hline $\begin{array}{l}\text { Coping flexibility } \\
\text { Elastyczne radzenie sobie }\end{array}$ & 14.84 & 5.23 & 4 & 28 \\
\hline $\begin{array}{l}\text { Hedonic tone } \\
\text { Ton hedonistyczny }\end{array}$ & 30.21 & 5.45 & 11 & 40 \\
\hline $\begin{array}{l}\text { Tense arousal } \\
\text { Pobudzenie napięciowe }\end{array}$ & 16.84 & 4.49 & 9 & 31 \\
\hline $\begin{array}{l}\text { Energetic arousal } \\
\text { Pobudzenie energetyczne }\end{array}$ & 31.28 & 5.50 & 16 & 40 \\
\hline
\end{tabular}


Table II. Descriptive statistics of examined variables according to gender Tabela II. Badane zmienne ze względu na płeć

\begin{tabular}{|l|c|c|c|c|c|c|}
\hline \multirow{2}{*}{$\begin{array}{l}\text { Variables } \\
\text { Zmienne }\end{array}$} & \multicolumn{2}{|c|}{$\begin{array}{c}\text { Girls } \\
\text { Dziewczęta }\end{array}$} & \multicolumn{2}{c|}{$\begin{array}{c}\text { Boys } \\
\text { Chłopcy }\end{array}$} & \multirow{2}{*}{$t$} & \multirow{2}{*}{} \\
\cline { 2 - 6 } & M & SD & M & SD & & \\
\hline $\begin{array}{l}\text { Coping flexibility } \\
\text { Elastyczne radzenie sobie }\end{array}$ & 16.94 & 5.22 & 14.10 & 5.05 & 2.75 & 0.007 \\
\hline $\begin{array}{l}\text { Hedonic tone } \\
\text { Ton hedonistyczny }\end{array}$ & 31.18 & 5.32 & 29.86 & 5.48 & 1.21 & 0.229 \\
\hline $\begin{array}{l}\text { Tense arousal } \\
\text { Pobudzenie napięciowe }\end{array}$ & 15.53 & 4.02 & 17.32 & 4.57 & -2.02 & 0.045 \\
\hline $\begin{array}{l}\text { Energetic arousal } \\
\text { Pobudzenie energetyczne }\end{array}$ & 31.74 & 5.72 & 31.12 & 5.44 & 0.56 & 0.574 \\
\hline
\end{tabular}

Table III. Use of marijuana according to gender Tabela III. Sięganie po marihuanę ze względu na płeć

\begin{tabular}{|l|c|c|c|c|c|c|}
\hline \multirow{2}{*}{$\begin{array}{l}\text { Variables } \\
\text { Zmienne }\end{array}$} & \multicolumn{2}{|c|}{$\begin{array}{c}\text { Girls } \\
\text { Dziewczęta } \\
n=34\end{array}$} & \multicolumn{2}{c|}{$\begin{array}{c}\text { Boys } \\
\text { Chłopcy } \\
n=95\end{array}$} & \multicolumn{2}{c|}{$\begin{array}{c}\text { General } \\
\text { Ogótem } \\
n=129\end{array}$} \\
\cline { 2 - 7 } & $n$ & $\%$ & $n$ & $\%$ & $n$ & $\%$ \\
\hline $\begin{array}{l}\text { Marijuana users } \\
\text { Sięganie po marihuanę }\end{array}$ & 7 & 21 & 43 & 45 & 50 & 39 \\
\hline $\begin{array}{l}\text { Marijuana non users } \\
\text { Niesięganie po marihuanę }\end{array}$ & 27 & 79 & 52 & 55 & 79 & 61 \\
\hline
\end{tabular}

initiation is 12 years of age ( $\mathrm{SD}=1.53)$. The most frequent physical effects linked to the taking of marijuana indicated by the subjects were shaking hands, headaches, motor coordination disorders and motor hyperactivity. Meanwhile, in the mental sphere, they reported anxiety, sadness, anger, joy and euphoria. The greatest proportion of the subjects was aware of the negative effects of marijuana on the body $(n=107 ; 83 \%)$.

Differences in terms of flexible coping with stress. As the results of analysis show, there is no statistically significant occurrence of differences in terms of flexible coping with stress between adolescent users and non-users of marijuana (Table V).

Differences in mood. The occurrence of statistically significant differences in the mood of adolescent users and non-users of marijuana has been confirmed. Subjects who used marijuana gained lower scores in the hedonic tone subscales (scores situated further from the pleasure pole) than non-user subjects. Also, user subjects scored higher in the tense arousal subscale
Najwięcej badanych deklarowało, że zażywało marihuanę dwa razy w miesiącu $(n=27 ; 21 \%)$, a najmniej codziennie $(n=1 ; 0,8 \%)$ (tab. IV). Średni wiek inicjacji narkotykowej to 12 lat $(\mathrm{SD}=1,53)$. Najczęstsze bezpośrednie skutki o charakterze fizycznym związane $\mathrm{z}$ zażywaniem marihuany, jakie wskazywali badani, to: drżenie rąk, bóle głowy, zaburzenia koordynacji ruchowej, nadaktywność ruchowa, a w sferze psychicznej: lęk, smutek, złość, radość, euforia. Najwięcej badanych miało świadomość negatywnego działania marihuany na organizm $(n=107 ; 83 \%)$.

Różnice w zakresie elastycznego radzenia sobie ze stresem. Jak wynika $\mathrm{z}$ analiz, nie występują istotne statystycznie różnice w zakresie elastycznego radzenia sobie ze stresem pomiędzy młodzieżą sięgającą i niesięgającą po marihuanę (tab. V).

Różnice w nastroju. Stwierdza się istotne statystycznie różnice $\mathrm{w}$ nastroju pomiędzy młodzieżą sięgającą i niesięgającą po marihuanę. Osoby, które używały marihuanę, osiągały niższe wyniki w podskali tonu hedonistycznego (wyniki usytuowane dalej od bieguna przyjemności) niż nieużywające 
Table IV. Frequency of marijuana use by respondents $(n=50)$

Tabela IV. Częstotliwość używania marihuany przez badanych $(n=50)$

\begin{tabular}{|l|c|c|c|c|c|c|}
\hline \multirow{2}{*}{$\begin{array}{l}\text { Variables } \\
\text { Zmienne }\end{array}$} & \multicolumn{2}{|c|}{$\begin{array}{c}\text { Girls } \\
\text { Dziewczęta } \\
n=7\end{array}$} & \multicolumn{2}{c|}{$\begin{array}{c}\text { Boys } \\
\text { Chtopcy } \\
n=43\end{array}$} & \multicolumn{2}{c|}{$\begin{array}{c}\text { General } \\
\text { Ogótem } \\
n=50\end{array}$} \\
\cline { 2 - 8 } & $n$ & $\%$ & $n$ & $\%$ & $n$ & $\%$ \\
\hline $\begin{array}{l}\text { Every day } \\
\text { Codziennie }\end{array}$ & 1 & 14.3 & - & - & 1 & 2 \\
\hline $\begin{array}{l}\text { Twice a week } \\
\text { Dwa razy w tygodniu }\end{array}$ & - & - & 10 & 23 & 10 & 20 \\
\hline $\begin{array}{l}\text { Once a week } \\
\text { Raz w tygodniu }\end{array}$ & - & - & 8 & 19 & 8 & 16 \\
\hline $\begin{array}{l}\text { Twice a month } \\
\text { Dwa razy w miesiącu }\end{array}$ & 4 & 57 & 23 & 53 & 27 & 54 \\
\hline $\begin{array}{l}\text { Once a month } \\
\text { Raz w miesiącu }\end{array}$ & 1 & 14.3 & - & - & 1 & 2 \\
\hline $\begin{array}{l}\text { No data } \\
\text { Brak odpowiedzi }\end{array}$ & 1 & 14.3 & 2 & 5 & 3 & 6 \\
\hline
\end{tabular}

Table V. Difference in coping flexibility according to marijuana use Tabela V. Różnica w elastycznym radzeniu sobie ze stresem ze względu na sięganie po marihuanę

\begin{tabular}{|l|c|c|c|c|c|c|}
\hline \multirow{2}{*}{$\begin{array}{l}\text { Variable } \\
\text { Zmienna }\end{array}$} & \multicolumn{2}{|c|}{$\begin{array}{c}\text { Marijuana users } \\
\text { Sięganie po } \\
\text { marihuanę }\end{array}$} & \multicolumn{2}{|c|}{$\begin{array}{c}\text { Marijuana non users } \\
\text { Niesięganie } \\
\text { po marihuanę }\end{array}$} & \multirow{2}{*}{$t$} & \multirow{2}{*}{$p$} \\
\cline { 2 - 6 } & M & SD & M & SD & & \\
\cline { 2 - 6 } $\begin{array}{l}\text { Coping flexibility } \\
\text { Elastyczne radzenie sobie }\end{array}$ & 15.22 & 5.22 & 14.59 & 5.05 & 0.65 & 0.514 \\
\hline
\end{tabular}

(anxiety-producing) than marijuana non-users (Table VI).

The links between mood and flexible coping with stress. Correlation analysis was conducted separately for adolescent users and non-users of marijuana. In the the user group, there was a lack of statistically significant relations between mood and flexible coping with stress (Table VII). In the non-user group, there were statistically significant relations between mood and flexible coping with stress. The adolescents that presented a higher result in the hedonic tone subscale (a result situated nearer the pleasure pole), were more effective at coping with stress in a flexible manner. Those with a higher result in the tense arousal subscale (anxiety-producing) coped with stress in a flexible manner to a lesser extent (Table VIII). tej substancji. Badani, którzy sięgali po marihuanę, osiągali wyższe wyniki w podskali pobudzenia napięciowego (lękotwórczego) od osób niesięgających po marihuanę (tab. VI).

Związki pomiędzy nastrojem a elastycznym radzeniem sobie ze stresem. Analizę korelacji przeprowadzono osobno dla młodzieży sięgającej i niesięgającej po marihuanę. W grupie młodzieży sięgającej po marihuanę stwierdza się brak istotnych statystycznie związków pomiędzy nastrojem a elastycznym radzeniem sobie ze stresem (tab. VII). W grupie osób niesięgających po marihuanę stwierdza się istotne statystycznie związki między nastrojem a elastycznym radzeniem sobie ze stresem. Młodzież, która prezentowała wyższy wynik w podskali tonu hedonistycznego (wynik usytuowany bliżej bieguna przyjemności), w sposób bardziej efektywny elastycznie radziła sobie ze stresem. Młodzi ludzie, którzy prezentowali wyższy wynik w podskali pobudzenia napięciowego (lękotwórczego), w mniejszym zakresie elastycznie radzili sobie ze stresem (tab. VIII). 
Table VI. Differences in mood according to marijuana use

Tabela VI. Różnice w zakresie nastroju ze względu na sięganie po marihuanę

\begin{tabular}{|l|c|c|c|c|c|c|}
\hline \multirow{2}{*}{$\begin{array}{l}\text { Variables } \\
\text { Zmienne }\end{array}$} & \multicolumn{2}{|c|}{$\begin{array}{c}\text { Marijuana users } \\
\text { Sięganie po marihuanę }\end{array}$} & \multicolumn{2}{|c|}{$\begin{array}{c}\text { Marijuana non users } \\
\text { Niesięganie po marihuanę }\end{array}$} & \multirow{2}{*}{$t$} & \multirow{2}{*}{$p$} \\
\cline { 2 - 6 } & $M$ & SD & M & SD & & \\
\hline $\begin{array}{l}\text { Hedonic tone } \\
\text { Ton hedonistyczny }\end{array}$ & 28.58 & 5.88 & 31.24 & 4.93 & -2.77 & 0.006 \\
\hline $\begin{array}{l}\text { Tense arousal } \\
\text { Pobudzenie napięciowe }\end{array}$ & 18.12 & 4.59 & 16.04 & 4.25 & 2.63 & 0.009 \\
\hline $\begin{array}{l}\text { Energetic arousal } \\
\text { Pobudzenie energetyczne }\end{array}$ & 30.36 & 5.07 & 31.86 & 5.70 & -1.52 & 0.131 \\
\hline
\end{tabular}

Table VII. Relationship between mood and coping flexibility in the marijuana user group of adolescents $(n=50)$ Tabela VII. Związek pomiędzy nastrojem a elastycznym radzeniem sobie ze stresem $\mathrm{w}$ grupie młodzieży sięgającej po marihuanę $(n=50)$

\begin{tabular}{|l|c|c|}
\hline $\begin{array}{l}\text { Mood subscales } \\
\text { Podskale nastroju }\end{array}$ & $r$ & $p$ \\
\hline $\begin{array}{l}\text { Hedonic tone } \\
\text { Ton hedonistyczny }\end{array}$ & 0.05 & 0.742 \\
\hline $\begin{array}{l}\text { Tense arousal } \\
\text { Pobudzenie napięciowe }\end{array}$ & 0.12 & 0.405 \\
\hline $\begin{array}{l}\text { Energetic arousal } \\
\text { Pobudzenie energetyczne }\end{array}$ & 0.09 & 0.534 \\
\hline
\end{tabular}

\section{- Discussion}

Mental health disorders and drug use belong to the unusually common problems affecting adolescents today $[2,45,46]$. The study the results of which are presented here was conducted on a group of adolescents mainly from rural areas and small towns. The study results do not however indicate unambiguously a differentiation in marijuana use in terms of adolescents' place of residence. Woynarowska's study [32] conducted within the HBSC project (Health Behaviour in School-aged Children), shows that the percent of 15-year-old adolescents using marijuana was independent of place of residence. Also Stępień's study [47], conducted in various regions of Poland, showed that slightly more respondents from the largest cities had had experience with drugs than those from the smaller towns, though this difference was not statistically significant.

In the analysis of the presented study, we first assessed averge level of flexible coping with stress in the study group, which revealed a score of $\mathrm{M}=14.84(\mathrm{SD}=5.23)$. The studied adolescents
Table VIII. Relationship between mood and coping flexibility in the non marijuana user group of adolescents $(n=79)$ Tabela VIII. Związek pomiędzy nastrojem a elastycznym radzeniem sobie ze stresem $w$ grupie młodzieży niesięgającej po marihuanę $(n=79)$

\begin{tabular}{|l|c|c|}
\hline $\begin{array}{l}\text { Mood subscales } \\
\text { Podskale nastroju }\end{array}$ & $r$ & $p$ \\
\hline $\begin{array}{l}\text { Hedonic tone } \\
\text { Ton hedonistyczny }\end{array}$ & 0.46 & $<0.001$ \\
\hline $\begin{array}{l}\text { Tense arousal } \\
\text { Pobudzenie napięciowe }\end{array}$ & -0.33 & 0.003 \\
\hline $\begin{array}{l}\text { Energetic arousal } \\
\text { Pobudzenie energetyczne }\end{array}$ & 0.22 & 0.056 \\
\hline
\end{tabular}

\section{- OmóWIENIE}

Zaburzenia zdrowia psychicznego i sięganie po substancje psychoaktywne należą do bardzo częstych problemów, które dotykają współczesną młodzież $[2,45,46]$. Badania, których wyniki zostały zaprezentowane, przeprowadzono w grupie młodzieży pochodzącej głównie ze wsi i małych miast. Wyniki badań nie wskazują jednak jednoznacznie na występowanie zróżnicowań w zakresie używania marihuany ze względu na miejsce zamieszkania adolescentów. Z badań Woynarowskiej [32] prowadzonych w ramach projektu HBSC wynika, żeodsetek młodzieży 15-letniej używającej marihuany był niezależny od miejsca jej zamieszkania. Także badania Stępień [47], które odbywały się w różnych regionach Polski, pokazały, że doświadczenia $\mathrm{z}$ używaniem narkotyków miała nieco większa liczba badanych w wielkim mieście niż w małym; różnica ta nie była jednak istotna statystycznie.

$\mathrm{W}$ analizach przedstawionych badań w pierwszej kolejności oceniono średni poziom elastycznego radzenia sobie ze stresem $\mathrm{w}$ badanej grupie, który wyniósł $\mathrm{M}=14,84(\mathrm{SD}=5,23)$. Badana młodzież osiągnęła wyższy wynik w elastycznym radzeniu sobie ze stresem $\mathrm{w}$ porównaniu $\mathrm{z}$ rówieśnikami $\mathrm{z}$ in- 
gained a higher result in flexible coping with stress compared to their peers in other studies $[48,49]$. One can suspect that this is associated with different competences with respect to coping with stress available to adolescents and which they apply in everyday life. What decides is sensitivity to stress and regulation of one's own activity in order to reduce the effects of stress [50].

Girls, more often than boys, report concerns and a higher level of stress $[51,52]$. This may be due to gender differences in coping with stress [53]. Girls have a tendency to ruminate and therefore to passive, repeating focussing of attention on one's own misfortunes and they tend to cope with stress more emotionally. Meanwhile, boys to a greater degree concentrate on the problem and more often apply escapist strategy. The avoidance approach of reacting to stress is also the domain of boys while girls more often seek the support of others and in a difficult situation attempt to solve problems $[54,55]$. The presented study also reveals gender differentiation in flexible coping with stress with girls being more effective than boys in this respect.

Despite the frequently noted lability of mood among adolescents, their characteristic feature is also a higher level of self-awareness. This results from youthful egocentrism based on an excessive absorption in their own thoughts together with mulling over what other people think of them [48]. Considering the subjects' mood, the boys were noticed to reveal a higher level of tense arousal (anxiety-producing) than the girls. The result gained may be considered in the context of stage of human development. Adolescents more often experience anxiety, embarrassment and a sense of guilt, but the source of these emotions is determined by gender. Boys more often experience negative emotions with respect to failure in activities they find important. They are also more taciturn than girls and do not say a lot about their problems [56].

The conducted research shows that 39\% of adolescents between 16 and 19 years-of-age used marijuana in the last 6 months (most often twice a month and twice a week). After taking gender into account, a greater proportion of boys than girls had used marijuana. In the light of Woynarowska's studies [32], 24\% of studied fifteen-year-olds had used marijuana at least once in their lives. The gained results are in keeping with ESPAD (European School Survey: a Project nych badań $[48,49]$. Można przypuszczać, że jest to związane $\mathrm{z}$ odmiennymi kompetencjami w zakresie radzenia sobie ze stresem, którymi dysponują młodzi ludzie i które wykorzystują w praktyce. Decyduje o nich wrażliwość na stres i regulacja własnego działania w celu zmniejszenia skutków stresu [50].

Dziewczęta częściej niż chłopcy zgłaszają zmartwienia i wyższy poziom stresu $[51,52]$. Fakt ten może wynikać $\mathrm{z}$ różnic między płciami w radzeniu sobie ze stresem [53] Dziewczęta mają tendencję do ruminacji, a więc pasywnego, powtarzającego się skupiania uwagi na niepowodzeniach, i bardziej emocjonalnie radzą sobie ze stresem. Natomiast chłopcy są skoncentrowani $\mathrm{w}$ większym stopniu na problemie i częściej stosują strategię oderwania się od problemu. Unikowy sposób reagowania na stres jest też domeną chłopców, podczas gdy dziewczęta częściej poszukują wsparcia u innych osób i w trudnej sytuacji podejmują próby rozwiązania problemu $[54,55]$. W prezentowanych badaniach wykazano zróżnicowanie płciowe w elastycznym radzeniu sobie ze stresem - dziewczęta były bardziej efektywne w tym zakresie niż chłopcy.

Pomimo często spotykanej labilności nastroju wśród adolescentów, ich charakterystyczną cechą jest także podwyższony poziom samoświadomości. Wynika to z młodzieńczego egocentryzmu polegającego na nadmiernym zaabsorbowaniu własnymi myślami, przy równoczesnym rozważaniu, co sądzą o nich inni ludzie [48]. Mając na uwadze nastrój badanych, chłopcy ujawniali wyższy poziom pobudzenia napięciowego (lękotwórczego) niż dziewczęta. Uzyskany wynik można rozpatrywać w kontekście etapu rozwoju człowieka. Adolescenci częściej odczuwają lęk, wstyd i poczucie winy, ale źródła tych emocji są zależne od płci. Chłopcy częściej doświadczają negatywnych emocji w związku z porażkami w zakresie ważnych dla nich rodzajów aktywności. Są także bardziej skryci niż dziewczęta i niewiele mówią o własnych problemach [56].

Z przeprowadzonych badań wynika, że 39\% młodzieży w wieku 16-19 lat używało marihuany w ciągu ostatnich 6 miesięcy (najczęściej dwa razy w miesiącu i dwa razy w tygodniu). Po uwzględnieniu płci badanych, większy odsetek chłopców niż dziewcząt używał marihuany. W świetle badań Woynarowskiej [32] 24\% badanych 15-latków używało marihuany kiedykolwiek w życiu. Uzyskane rezultaty są zbieżne $\mathrm{z}$ wynikami badań szkolnych ESPAD z 2015 r. [30], w których wśród starszej młodzieży można zaobserwować trend wzrostowy sięgania po marihuanę. Używanie marihuany jest też bardziej 
on Alcohol and Drugs) results from 2015 [30], in which a rising trend in marijuana use is observed among the older youth. Also, marijuana use is more widespread among boys than girls. The differences between boys and girls in the frequency of marijuana/hashish use throughout their lives clearly narrowed in 2014. Currently it is a difference above the limit of statistical significance $(p=0.078)$. However, over the last thirty days, boys used marijuana/hashish significantly more often than girls $(p=0.004)$ [32].

Early and frequent marijuana use may cause various negative psychosocial and health consequences including dependency and other drugs use $[57,58]$. There is an especially high risk associated with very early age of marijuana use (13 years and less), with which there are associated other risk behaviours (smoking cigarettes, drinking and very early sexual initiation) [59]. As the gained study results show the initiation of marijuana use by adolescents took place at a very early age (12 years).

Research investigating the links between marijuana use and regulation of mood reveals two tendencies [60-64]. The first shows that smoking marijuana may cause depression symptoms (low mood) $[60,62]$. Regular use by adolescents is linked to high risk of the development of psychotic symptoms, especially the early onset of psychosis [63]. Marijuana use co-occurs also with weak, inadequate in terms of age social skills, with social maladjustment and increased risk of suicide $[64,65]$. However, the other tendency shows that marijuana use contributes to reduced intensity of depression symptoms in adolescents [61]. In the light of the presented study results, marijuana using adolescents experienced smaller pleasure and higher tense arousal (anxiety-producing) than non-users. Dollard [after 66] showed that the most prone to enter into all kinds of psychoactive substance dependence were persons characterised by a high state of anxiety and internal tension. This kind of person uses psychoactive substances to reduce the emotional states they are burdened with. The effect of this activity is relief gain, but at the same time increasing the probability of a similar solution to their problem ever more frequently and using ever greater doses. It is worth also considering Solomon's opponent process theory [after 67], which assumes that every psychoactive substance capable of leading to dependency at rozpowszechnione wśród chłopców niż dziewcząt. Różnice między chłopcami i dziewczętami w częstości używania marihuany/haszyszu w ciągu całego życia wyraźnie zmniejszyły się w 2014 r. Obecnie jest to różnica powyżej granicy istotności statystycznej $(p=0,078)$. Nadal jednak chłopcy znacznie częściej niż dziewczęta używali marihuany/haszyszu w ostatnich 30 dniach $(p=0,004)$ [32].

Wczesne i częste używanie marihuany może spowodować różne negatywne konsekwencje psychospołeczne i zdrowotne, także uzależnienie i zażywanie innych narkotyków [57, 58]. Szczególne ryzyko wiąże się z bardzo wczesnym wiekiem używania marihuany (13 lat i mniej), z którym współistnieją inne ryzykowne zachowania (palenie tytoniu, picie alkoholu, bardzo wczesna inicjacja seksualna) [59]. Uzyskane wyniki badań pokazują, że inicjacja używania marihuany przez młodzież następowała w bardzo wczesnym wieku (12 lat).

Badania poszukujące związków pomiędzy używaniem marihuany a regulacją nastroju pozwalają dostrzec dwie tendencje [60-64]. Pierwsza $\mathrm{z}$ nich pokazuje, że palenie marihuany może wywoływać symptomy depresyjne (obniżony nastrój) [60, 62]. Regularne jej przyjmowanie przez adolescentów wiąże się z podwyższonym ryzykiem rozwoju objawów psychotycznych, szczególnie wczesnego początku psychozy [63]. Używanie marihuany współwystępuje także ze słabymi, nieadekwatnymi do wieku, umiejętnościami społecznymi, z nieprzystosowaniem społecznym i podwyższonym ryzykiem samobójstwa $[64,65]$. Natomiast druga tendencja pokazuje, że używanie marihuany wpływa na mniejsze nasilenie objawów depresyjnych u młodzieży [61]. W świetle prezentowanych wyników badań młodzież sięgająca po marihuanę doznawała mniejszej przyjemności i większego pobudzenia napięciowego (lękotwórczego) niż osoby niesięgające po marihuanę. Dollard [za: 66] wskazywał, że najbardziej podatne na wchodzenie we wszelkiego rodzaju uzależnienia od substancji psychoaktywnych są osoby charakteryzujące się wysokim stanem niepokoju i napięcia wewnętrznego. Takie osoby sięgają po substancje psychoaktywne w celu zredukowania silnie ich obciążających stanów emocjonalnych. Efektem tych działań jest uzyskanie ulgi, ale jednocześnie zwiększone prawdopodobieństwo podobnego rozwiązywania problemów - coraz częściej i ze stosowaniem coraz większej dawki. Warto odnieść się również do teorii procesów przeciwstawnych Solomona [za: 67], która zakłada, że każda substancja psychoaktywna mogąca doprowadzić do 
first elicits pleasant mental states. In the process of substances abuse there is however the phenomenon of tolerance to their activity. In order to achieve a similar state, it becomes necessary to increase the dose or reduce the intervals between subsequent doses. The original intensive pleasure never returns [68]. However, the substance withdrawal results in the appearance the opposite negative emotional states like strong anxiety and even panic [68].

Even though numerous studies reveal links between coping strategies for stress and psychoactive substance taking [69-72], the results of conducted research did not confirm variation in the scope of flexible coping with stress between adolescent users and non-users of marijuana. Flexible coping with stress concerns the individual's capacity to effectively modify coping strategies depending on changing conditions in the stressful situation [12]. In the context of the results gained, one may propose the hypothesis that flexibility in coping is reflected in the opposite fashion in users and non-users of marijuana. This is also confirmed in the following results of these studies. Considering marijuana use in terms of avoidance strategies, one may conclude that the flexibility in coping with stress is expressed in the modification of the amount and frequency of marijuana use.

Further results showed that mood is linked to flexible coping with stress but depending on whether the adolescents use marijuana or not. Among marijuana users, no link was noted between mood and flexible coping with stress. This may be, among others, due to the fact that marijuana users, as well as dependent users, try to adapt to society by repressing their authentic emotions but at the same time releasing them again with the aid of drugs in an apparently controlled manner as if on demand: arousal, calmness, relaxation and sense of happiness. In the context of growing up, they deny their problems, changes and themselves. Marijuana makes everyday problems disappear and life becomes carefree [73]. However, among adolescents who do not use marijuana there is a link between mood and flexible coping with stress. Adolescent non-users of marijuana, who experienced more pleasure, were more effective at flexible coping with stress. However those who present- uzależnienia wywołuje początkowo przyjemne stany psychiczne. W procesie nadużywania substancji psychoaktywnych pojawia się jednak zjawisko tolerancji na ich działanie. W celu osiągnięcia porównywalnego stanu konieczne staje się przyjęcie większej dawki lub zmniejszenie interwału pomiędzy przyjmowaniem kolejnych porcji. Pierwotna, intensywnie odczuwana przyjemność nigdy się nie powtarza [68]. Odstawienie substancji skutkuje natomiast pojawieniem się przeciwstawnych negatywnych stanów emocjonalnych - silnego lęku, a nawet paniki [68].

Chociaż liczne badania pokazują występowanie związków pomiędzy strategiami radzenia sobie ze stresem i sięganiem po substancje psychoaktywne [69-72], wyniki przeprowadzonych badań nie potwierdziły zróżnicowań w zakresie elastycznego radzenia sobie ze stresem pomiędzy młodzieżą sięgającą i niesięgającą po marihuanę. Elastyczne radzenie sobie ze stresem dotyczy zdolności jednostki do efektywnej modyfikacji strategii radzenia sobie w zależności od zmieniających się warunków sytuacji stresującej [12]. W kontekście uzyskanych wyników można wysunąć hipotezę, że elastyczność w radzeniu sobie odzwierciedla się w odmienny sposób wśród młodzieży sięgającej i niesięgającej po marihuanę, co potwierdzają również następne wyniki niniejszych badań. Patrząc na sięganie po marihuanę w kategoriach strategii unikowych, można sądzić, że elastyczność $\mathrm{w}$ radzeniu sobie ze stresem wyraża się w modyfikacji ilości i częstości używania marihuany.

Kolejne wyniki pokazały, że nastrój wiąże się z elastycznym radzeniem ze stresem, ale w zależności od tego, czy młodzież używa marihuany czy też nie. Wśród młodzieży sięgającej po marihuanę nie zidentyfikowano związku nastroju z elastycznym radzeniem sobie ze stresem. Brak tego związku może wynikać m.in. z faktu, że osoby używające marihuany, także uzależnione od niej, próbują przystosować się do społeczeństwa, zwalczając swoje autentyczne uczucia, ale jednocześnie wywoływać je ponownie za pomocą narkotyków w sposób z pozoru kontrolowany, jakby na zawołanie: pobudzenie, uspokojenie, relaks, poczucie szczęścia. W kontekście dojrzewania zaprzeczają problemom, zmianom, sobie. Marihuana powoduje, że znikają codzienne problemy, życie staje się sielankowe [73]. Natomiast u młodzieży nieużywającej marihuany występuje związek między nastrojem a elastycznym radzeniem sobie ze stresem. Młodzi ludzie niezażywający marihuany, którzy doznawali więcej przyjemności, byli bardziej efektywni w elastycznym radzeniu sobie ze 
ed greater tense arousal (anxiety-producing), so were more nervous, to a lesser extent flexibly coped with stress. This may be linked to the fact that low mood has a negative effect on the individual's way of thinking $[9,74]$.

\section{Study constraints}

The analysis fails to consider the frequency of marijuana use as the studied group was not large enough to represent the particular frequencies of marijuana use with a sufficient number of adolescents. It is suspected that the frequency of use of this substance would have a significant impact on the gained results. The research was conducted among adolescents from rural areas and small towns. It would also be worthwhile to conduct it on adolescents from large cities. The respondents were recruited at vocational and technical schools. We suspect it would be unusually valuable to survey the students of other kinds of post primary schools. The above limitations suggest a careful interpretation of the presented study results.

\section{- Conclusions}

1. There were no statistically significant differences in flexible coping with stress between adolescent users and non-users of marijuana.

2. Adolescent marijuana users gain less pleasure and experience greater tense arousal than those who are not users.

3. In the adolescent marijuana users group, there is no link between mood and flexible coping with stress.

4. Adolescent non-users of marijuana, who presented higher results in the hedonic tone subscale (nearer the pleasure pole), were more effective at flexible coping with stress.

5. Adolescents who did not use marijuana and presented higher results in the tense arousal subscale (anxiety-producing) to a lesser extent coped with stress in a flexible manner. stresem. Natomiast ci z nich, którzy prezentowali większe pobudzenie napięciowe (lękotwórcze), czyli byli bardziej zdenerwowani, w mniejszym zakresie elastycznie radzili sobie ze stresem - co można wiązać z faktem, że obniżony nastrój wywiera niekorzystny wpływ na sposób myślenia jednostki $[9,74]$.

\section{Ograniczenia badania}

W analizach zaniechano uwzględnienia częstotliwości sięgania po marihuanę, ponieważ badana grupa nie była na tyle liczna, żeby poszczególne częstości używania marihuany mogły być reprezentowane przez wystarczającą liczbę adolescentów. Przypuszcza się, że częstość sięgania po tę substancję miałaby istotne znaczenie dla uzyskanych rezultatów. Badania zostały przeprowadzone wśród młodzieży pochodzącej ze wsi i małych miast. Warto byłoby przeprowadzić je również $\mathrm{z}$ młodzieżą $\mathrm{z}$ dużych miast. Respondenci rekrutowali się ze szkół zawodowych i technikum. Przypuszcza się, że niezwykle wartościowe byłoby zbadanie uczniów w innych typach szkół ponadpodstawowych. Powyższe ograniczenia skłaniają do ostrożnej interpretacji zaprezentowanych wyników badań.

\section{- WNIOSKI}

1. Nie występują istotne statystycznie różnice w elastycznym radzeniu sobie ze stresem między młodzieżą sięgającą i niesięgającą po marihuanę.

2. Młodzież sięgająca po marihuanę osiąga mniejszą przyjemność, a większe pobudzenie napięciowe niż młodzież niesięgająca po marihuanę.

3. W grupie młodzieży sięgającej po marihuanę nie występuje związek nastroju z elastycznym radzeniem sobie ze stresem.

4. Młodzież niezażywająca marihuany, która prezentowała wyższe wyniki w podskali tonu hedonistycznego (bliżej bieguna przyjemności), była bardziej efektywna w elastycznym radzeniu sobie ze stresem.

5. Młodzież niezażywająca marihuany, która prezentowała wyższe wyniki w podskali pobudzenia napięciowego (lękotwórczego) w mniejszym zakresie elastycznie radziła sobie ze stresem.

\section{Conflict of interest/Konflikt interesów}

None declared./Nie występuje. 


\section{Financial support/Finansowanie}

None declared./Nie występuje.

\section{Ethics/Etyka}

The work described in this article has been carried out in accordance with the Code of Ethics of the World Medical Association (Declaration of Helsinki) on medical research involving human subjects, EU Directive (210/63/EU) on protection of animals used for scientific purposes, Uniform Requirements for manuscripts submitted to biomedical journals and the ethical principles defined in the Farmington Consensus of 1997.

Treści przedstawione w pracy są zgodne z zasadami Deklaracji Helsińskiej odnoszącymi się do badań z udziałem ludzi, dyrektywami EU dotyczącymi ochrony zwierząt używanych do celów naukowych, ujednoliconymi wymaganiami dla czasopism biomedycznych oraz z zasadami etycznymi określonymi w Porozumieniu z Farmington w 1997 roku.

\section{References/Piśmiennictwo}

1. Diekstra R, Garnefski N. On the nature, magnitude, and causality of suicidal behaviors: An international perspective. Suicide Life Threat Behav 1995; 25: 36-57.

2. Low N, Dugas E, O’Loughlin E, Rodriguez D, Contreras G, Chaiton M, et al. Common stressful life events and difficulties are associated with mental health symptoms and substance use in young adolescents. Psychiatry 2010; 12: 116-22.

3. Timko C, Moos RH, Michelson DJ. The contexts of adolescent's chronic life stressors. Am J Community Psychol 1993; 21: 397-420.

4. Talik E. Specyfika stresu szkolnego i strategie radzenia sobie z nim przez młodzież w okresie dorastania. Horyzonty Psychologii 2011; 1(1): 127-37.

5. Kostrzewa-Zabłocka E, Ponurek B. Stres u młodzieży pierwszych klas licealnych. Zdrowie i Dobrostan 2015; 1(15): 191-203.

6. Zhang T, Kang X, Zhang F. Study on the relationship of life events, coping styles and negative emotion among college students. Journal of Agricultural University of Hebei 2008; 10: 449-52.

7. Yang M, Wang T, Li J. The study on correlation between college students' depressive emotion and their coping styles. China Journal of Health Psychology 2009; 17: 8-10.

8. Liu Z. A perceived stress mediating model study about problem focused styles of coping in university students affect mental health. Chinese Journal of Clinical Psychology 2008; 16: 170-72.

9. Nagase Y, Uchiyama M, Kaneita Y, Li L, Kaji T, Takahashi S, et al. Coping strategies and their correlates with depression in the Japanese general population. Psychiatry Res 2009; 168: 57-66.

10. Gan Y, Zhang Y, Wang X, Wang S, Shen X. The coping flexibility of neurasthenia and depressive patients. Pers Individ Diff 2006; 40: 859-71.

11. Zhang Y, Yan K, Wang J. A path analysis on life events, negative automatic thoughts, coping style and depression. Psychological Development and Education 2005; 1: 96-9.

12. Kato T. Development of the Coping Flexibility Scale: evidence for the coping flexibility hypothesis. J Couns Psychol 2012; 59: 262-73.

13. Cheng C. Cognitive and motivational processes underlying coping flexibility: a dual-process model. J Pers Soc Psychol 2003; 84: 425-38.

14. Fresco DM, Williams NL, Nugent NR. Flexibility and negative affect: Examining the associations of explanatory flexibility and coping flexibility to each other and to depression and anxiety. Cognitive Ther Res 2006; 30: 201-10.

15. Lam CB, McBride-Chang CA. Resilience in young adulthood: The moderating influences of gender-related personality traits and coping flexibility. Sex Roles 2007; 56: 159-72.

16. Cheng C, Cheung WL. Cognitive processes underlying coping flexibility: Differentiation and integration. J Personal 2005; 73: 859-86. 
17. Brandtstädter J. Goal pursuit and goal adjustment: Self-regulation and intentional self-development in changing developmental contexts. Adv Life Course Res 2009; 14: 52-62.

18. Murabito JM, Pencina MJ, Zhu L, Kelly-Hayes M, Shrader P, D'Agostino RB. Temporal trends in self-reported functional limitations and physical disability among the communitydwelling elderly population: The Framingham Heart Study. Am J Public Health 2008; 98 : 1256-62.

19. Donaldson D, Prinstein MJ, Danovsky M, Spirito A. Patterns of children's coping with life stress: Implications for clinicians. Am J Orthopsychiatry 2000; 70: 351-59.

20. Frydenberg E, Lewis R. Academic and general wellbeing: The relationship with coping. Aust J Guid Couns 1999; 9: 19-36.

21. Bomba J. Trauma i stress - znaczenie dla medycyny. Psychiatr Prakt Ogólnolek 2002; 2(4): 225-28.

22. Sikora R, Pisula E. Przyczyny stresu i strategie radzenia sobie ze stresem u młodzieży w wieku 14-16 lat. Polskie Forum Psychologiczne 2002; 2: 110-22.

23. Ziółkowska B. Okres dorastania. Jak rozpoznać ryzyko i jak pomagać? In: Brzezińska A. (ed.) Psychologiczne portrety czlowieka. Gdańsk: GWP; 2005, p. 379-422.

24. Compas BE, Conno-Smith JK, Saltzman H, Thomsen AH, Wadsworth ME. Coping with stress during childhood and adolescence: problems, progress and potential in theory and research. Psychol Bull 2001; 127: 87-127.

25. Woronowicz BT. Bez tajemnic: o uzależnieniach i ich leczeniu. Warszawa: Instytut Psychiatrii i Neurologii; 2001.

26. Mellibruda J. Integracyjna psychoterapia uzależnień. Teoria i praktyka. Warszawa: Instytut Psychologii Zdrowia PTP; 2006.

27. Wojcieszek K. Profilaktyka używania substancji psychoaktywnych - wybrane problemy. In: Jędrzejko M. (ed.) Narkomania - spojrzenie wielowymiarowe. Warszawa: Oficyna Wydawnicza ASPRA-JR; 2010, p. 45-57.

28. Jędrzejko M. Marihuana fakty, marihuana mity. Wrocław: Wrocławskie Wydawnictwo Naukowe Atla 2; 2011.

29. Kruczek A. Stosowanie środków psychoaktywnych przez nieletnie przestępczynie. Alkoholizm i Narkomania 2013; 26(4): 331-48.

30. Sierosławski J. Używanie alkoholu i narkotyków przez młodzież szkolną. Raport z ogólnopolskich badań ankietowych zrealizowanych w 2015 r. Europejski program badań ankietowych w szkołach ESPAD. Warszawa: Krajowe Biuro ds. Przeciwdziałania Narkomanii i Państwowa Agencja Rozwiązywania Problemów Alkoholowych; 2015.

31. Woynarowska B, Mazur J. Zdrowie młodzieży szkolnej w Polsce. Zachowania zdrowotne i samoocena zdrowia. Warszawa: UW; 1999.

32. Woynarowska B. Używanie marihuany/haszyszu przez młodzież piętnastoletnią. In: Mazur J. (ed.) Zdrowie i zachowania zdrowotne młodzieży szkolnej $w$ Polsce na tle wybranych uwarunkowań socjodemograficznych. Warszawa: Instytut Matki i Dziecka; 2015, p. 187-201.

33. Liu X, Tao S. The relationship among different stress sources, coping strategies and female university students' negative feelings. Acta Psychol Sin 2005; 37: 637-49.

34. Cascone T. Upregulated stromal EGFR and vascular remodeling in mouse xenograft models of angiogenesis inhibitor-resistant human lung adenocarcinoma. J Clin Invest 2011; 121(4): 1313-28.

35. Kato T. The impact of coping flexibility on the risk of depressive symptoms. PLoS One 2015; DOI:10.1371/journal.pone.0128307.

36. Russell JA, Feldman Barrett L. Core affect, prototypical emotional episodes, and things called emotion: dissecting the elephant. J Pers Soc Psychol 1999; 76: 805-19.

37. Watson D. Mood and temperament. New York: Guilford Press; 2000.

38. Goryńska E. Przymiotnikowa Skala Nastroju UMACL Geralda Matthewsa, A. Grahama Chamberlaina, Dylana M. Jonesa. Podręcznik. Warszawa: Pracownia Testów Psychologicznych Polskiego Towarzystwa Psychologicznego; 2005.

39. Nęcka E. Pobudzenie intelektu. Zarys formalnej teorii inteligencji. Kraków: Universitas; 2000.

40. Basińska MA. Polish version of Coping Flexibility Scale - the summary of research results. In: Basińska MA. (ed.) Coping flexibility with stress in health and in disease. 
Elastyczne radzenie sobie ze stresem $w$ zdrowiu $i$ w chorobie. Bydgoszcz: Wydawnictwo UKW; 2015, p. 272-94.

41. Jones DR. Living in the Moment: Daily life assessments of mindfulness mediation on stress, coping flexibility, and well-being. Western Washington University; 2015.

42. Mazur J, Małkowska-Szkutnik A. Wyniki badań HBSC 2010. Raport techniczny. Warszawa: Instytut Matki i Dziecka; 2011.

43. Ostaszewski K, Bobrowski K, Borucka A, Okulicz-Kozaryn K, Pisarska A, Raduj J, et al. Monitorowanie zachowań ryzykownych i problemów zdrowia psychicznego młodzieży. Badania mokotowskie 2012. Warszawa: IPiN; 2013.

44. Hill D, Mrug S. School-level correlates of adolescent tobacco, alcohol and marijuana use. Subst Use Misuse 2015; 50(12): 1518-28.

45. Ostaszewski K. Zachowania ryzykowne młodzieży w perspektywie mechanizmów resilience. Warszawa: IPiN; 2014.

46. Lewinsohn PM, Rohde P, Seeley JR. Major depressive disorder in older adolescents: prevalence, risk factors, and clinical implications. Clin Psychol Rev 1998; 18(7): 765-94.

47. Stępień E. Psychospołeczne korelaty używania narkotyków wśród młodzieży. Przegląd badań z lat 1997-2002. Warszawa, IPiN; 2004.

48. Makowski A. Niedostosowanie społeczne młodzieży i jej resocjalizacja. Warszawa: PWN; 1994.

49. Grzankowska I, Minda M. Samoocena i elastyczne radzenie sobie ze stresem w grupie młodzieży szkół gimnazjalnej i ponadgimnazjalnej. In: Basińska MA. (ed.) Coping flexibility with stress in health and in disease. Elastyczne radzenie sobie ze stresem $w$ zdrowiu $i$ w chorobie. Bydgoszcz: Wydawnictwo UKW; 2015, p. 61-98.

50. Kruczek A. Emotion control and anger expression style in relation to coping flexibility in students of middle and secondary schools. In: Basińska MA. (ed.) Coping flexibility with stress in health and in disease. Elastyczne radzenie sobie ze stresem $w$ zdrowiu $i w$ chorobie. Bydgoszcz: Wydawnictwo UKW; 2015, p. 99-120.

51. Skinner EA, Zimmer-Gembeck MJ. The development of coping. Annu Rev Psychol 2007; 58: 119-44.

52. Lewis CE, Siegel J, Lewis IL. Feeling bad: Exploring sources of distress among preadolescent children. Am J Public Health 1984; 74: 117-22.

53. Calvete E, Orue I, Estévez A, Villardón L, Padilla P. Cyberbullying in adolescents: Modalities and aggressors' profile. Comput Human Behav 2010; 26(5): 1128-35.

54. Papadakis AA, Prince RP, Jones NP, Strauman TJ. Self-regulation, rumination, and vulnerability to depression in adolescent girls. Dev Psychopathol 2006; 18(3): 815-29.

55. Plancherel B, Bolonini M, Halfon O. Coping strategies in early and mid-adolescence: differences according to age and gender in a community sample. Eur Psychol 1998; 3(3): 192-201.

56. Brzezińska A. Niezbędnik dobrego nauczyciela. Warszawa: Instytut badań edukacyjnych; 2014.

57. Eschenbeck H, Kohlmann CW, Lohaus A. Gender differences in coping strategies in children and adolescents. $J$ Ind Diff 2007; 28(1): 18-26.

58. MacLeod J, Oakes R, Copello A. Psychological and social sequel of cannabis and other illicit drug use by young people: a systematic review of longitudinal, general population studies. Lancet 2004; 363: 1579-88.

59. Kokkevi A, Nic Gabhainn S, Spyropoulou M. Early initiation of cannabis use: across-national European perspective. J Adolesc Health 2006; 39: 712-19.

60. Degenhardt L, Hall W, Lynskey M. Testing hypotheses about the relationship between cannabis use and psychosis. National Drug and Alcohol Research Centre, 2003, University of NSW, Sydney, NSW 2052.

61. Denson TF, Earleywine M. Decreased depression in marijuana users. Addict Behav 2006; 31: 738-42.

62. Moore THM, Zammit S, Lingford-Hughes A, Barnes TRE, Jones PB, Burke M, et al. Cannabis use and risk of psychotic or affective mental health outcomes: A systematic review. Lancet 2007; 370: 319-28. 
63. Casadi P, Fernandes C, Murray RM, Di Forti M. Cannabis use in young people: The risk for schizophrenia. Neurosci Biobehav Rev 2011; 35: 1779-87.

64. Radhakrishnan R, Wilkinson ST, D'Souza1 DC. Gone to Pot - A review of the association between cannabis and psychosis. Front Psychiatry 2014; 5(24): 1-24.

65. Jaycox LH, Stein BD, Paddock S, Miles JN, Chandra A, Meredith LS, et al. Impact of teen depression on academic, social, and physical functioning. Pediatrics 2009; 124(4): 596-605.

66. Rogala-Obłękowska J. Specyfika terapii uzależnień. Remedium 2002; 9: 18-20.

67. Kostowski W. Uzależnienia - podstawowe teorie i pojęcia. Psychiatria 2005; 2: 61-76.

68. Cierpiałkowska L. Alkoholizm: przyczyny, leczenie, profilaktyka. Poznań: Wydawnictwo Naukowe UAM; 2001.

69. Simons RL, Robertson JF. The impact of parenting factors, deviant peers, and coping style upon adolescent drug use. Fam Relat 1989; 38: 273-82.

70. Sanchez V, Moore CF, Brunzell DH, Lynch WJ. Effect of wheel-running during abstinence on subsequent nicotine-seeking in rats. Psychopharmacology 2013; 231(8): 1753-62.

71. Cooper ML, Russell M, Skinner JB, Frone MR, Mudar P. Stress and alcohol use: Moderating effects of gender, coping, and alcohol expectancies. J Abnorm Psychol 1992; 101: 139-52.

72. Hasking PA, Oei T. The complexity of drinking: Interactions between the cognitive and behavioural determinants of alcohol consumption. Addict Res Theory 2004; 12: 469-88.

73. Miller A. Zniewolone dzieciństwo. Poznań: Wydawnictwo Media Rodzina; 1999.

74. Strelau J, Zawadzki B, Oniszczenko W, Sobolewski A, Pawłowski P. Temperament i style radzenia sobie ze stresem jako moderatory zespołu stresu pourazowego w następstwie przeżytej katastrofy. In: Strelau J. (ed.) Osobowość a ekstremalny stres. Gdańsk: Gdańskie Wydawnictwo Psychologiczne; 2004, p. 467-82. 